\title{
The Transformation of Marriage Relationship: Digital Sexuality
}

\author{
Olcay S. ${ }^{1}$ \\ ${ }^{1}$ Sümeyya OLCAY, İstanbul Aydın University, (Turkey) \\ e-mail: sumeyyaolcay@gmail.com
}

\begin{abstract}
The technology, which begins to reshape almost every phase of fields such as industry, agriculture, health, economy, defense, has also started to affect the human and social life and to take a significant role in the decision processes with digitalizing. The most explicit feature which we encounter within the new digital world in which the needs have been changing with the social platforms is the fact that the digital interactions have gradually substituted for the face-to-face human connections worldwide. Now, socializing has formed a digital identity in the digital platform where it has been thought that more free space has been provided within the context of human and society relations. New technological tendencies and social cases have started to emerge with this identity. Digital identity has been reaching up to a point where it affects and guides real life in the meantime. This process which is affected by choices and lifestyles leads to the emergence of the concept of digital sexuality based on sexual tendencies. With the rapid development of artificial intelligence, the fact that people make a relationship with smart devices as they do with people and the admiration for digital/anime characters have been bringing out this situation up to the marriage point. Digital sexuality/marriage within the context of digital characters-human relations, its causes, and future, and the effect of technology on collective life have been approached in this article with the fact that digitalizing has gained huge ground in our lives. The case analysis has been done with an individual, who executed a digital marriage, with a qualitative research approach and by the usage of semi-structured interview style.
\end{abstract}

Keywords: Digitalizing, Digital Culture, Artifical Intelligence, Digital Marriage, Digital Sexuality.

\section{Introduction}

Seeing the internet and technology as achieving the pure knowledge and spreading it in today, is against the nature of this big world. Since we have left behind web 1.0, which is a pile of static web sites in our lives, and web 2.0, which provides the interaction between pages and bringing the user to a more active position on the internet. Now we are face-to-face with a web 3.0 revolution, which manages the content control software and that recognizes us due to date base systems. The artificial intelligence technology, which works like a human brain, and is capable of programming, meets the needs by recognizing them in its own system, has been improving each passing day, and starting to spread into every field. This is one of the most important improvements in the technology world, even the pioneer.

Digitalizing, which we can also refer to as digitizing of the objects or the things, has been spreading to all the layers of human and society dynamics. It is a visible reality that the most of the processes, which have been done through muscle and mind power in the fields such as industry, agriculture, defense, health, have now been started to be substituted by the digital systems. Constraining the digitalizing process with only the tools used leads to lacking the power and the nature that the technology holds. Since as a social entity, the human nature, which has enhanced the communication because of the communication needs from the cave drawings in the first ages to the fingers touches on the phone, has also been affected by the digitalizing. With a clearer expression, humankind has been acting into executing the existence in the digital world along with existing in the real world.

One of the incomes of the technology that affects human and social life and that provides the transformation of some social processes into different dimensions is the digital platforms. Digital platforms include such many transformations as gaining information, giving information, speaking, 
moving, having something moved, interacting, connecting, which are the parts of communication. Here, social media platforms play a dominant role. These platforms have started to substitute for the interaction of people one-to-one. The logins being opened in these courses, has the potential to share the individual's own feelings and thoughts, comments, likes as in the forms message, picture, and video in the case of being signed up with ad username and also in the case of being not locked up of the accounts, they have the potential to share them with both the other users on the social media and with the whole world. It is also the target group of the other users. The communication of the people with the others, socializing process, interaction have been executed on the social platforms, which we refer to them as new media. A lifestyle based on the sharing of what is being lived in real life has considerably started to be common among particularly the digital natives and the hybrids. The gathering of people, events, and being in face-to-face interaction that exists in real life in this process, with a clearer expression socializing has begun the digitalize in the new media extension. We can claim that now a digital culture fulfills the norms for that an individual exists in a digital world as in the real world to sustain the existence in this whole process.

The fact that digitalizing has taken its place in the humankind's life that much and even many transactions and steps have been sustained with the possibilities that the digital provides has being executed through artificial intelligence technology. In this information society in which now we live this era, the technology of gaining meaningful integrity of the data which is produced more than already existing information, contents and using them in case of being in need has been executed through artificial intelligence. Artificial'izing software of intelligence, which is an abstract concept, and transformation into a concrete form with programming and have them gain the specialty of being "smart" with this transformation can be defined as artificial intelligence. The artificial intelligence technology that exists in each phase of digitalizing is the main factor of digital platforms. Since, the main structure of digital platforms has a neural network that follows the pieces of information, data, the related areas, demographical features, likes and hates of all the users who have a digital identity. Artificial intelligence is trying to reach the human brain's complicated structure that has not been solved entirely yet, at this point. And through using the same language it has been responding to millions of user's needs in the digital platforms and offering interaction and communication.

Now, artificial intelligence has been sustaining what people need in smartphones beside social media platforms that are a part of digital culture, which is the transformed shape of socializing. Accordingly, digital assistants programmed for both telephones and for a separate device in special, are one of the most significant examples of artificial intelligence improvement. The remarkable point here is that the technology has the willing to provide almost all the needs of the individual in the case where he/she needs for communication through digital means in the personal and social process. Only the good will of fulfilling one's need is not contained here for certain, because with cookies technology, collecting the data of the existing identities in the digital, storage, and servicing them excluding the will of the individual to another entity or institution are also being executed with artificial intelligence and through digital platforms that it sustains its existence.

Humankind, as Maslow also puts it in the "Hierarchy of Needs", feels the physiological, safety, love and belonging, esteem and self-actualizing needs. The necessity of fulfillment of these needs has always been felt. And the tools and causes in the fulfilling process have changed through history with technical information. And here the topics are the change in, especially love, belonging, self-actualizing, esteem, forming a place where he/she will love and feel comfortable and offering the sustainability of these places in the fulfillment of these needs with the improvement of technical information. Besides being the subject of the article, when we approach the subject from the digital sexuality perspective, the individual's willingness of sharing the feelings with an opposite sex, loving him/her, desiring to be loved, respecting, desiring to be respected, and the need to be happy with all these has been encountered newly and that it is the question of being popular is a remarkable topic.

Lifestyle, preferences, and attitudes of an individual who has a digital identity, have started to differentiate in the digital culture where he/she belongs differentiating from what is in real life. Both relations between friends and information gaining-giving, communication process, information/content process, speaking, behavior process, and relationships and marriage process also have started to Show differences in the digital world. Here, one of the most important points what needs to be argued and evaluated under a scientific infrastructure is the relationships and the marriage extension. The situation of Akihiko Kondo who married a hologram structure of Hatsune Miku, to whom Akihiko admires as a cartoon character in November 2018, Japan, made a tremendous impact worldwide. The fact that the 
institution of marriage that owns a spiritual system including such feeling and thoughts as physical contact, loving and being loved, esteem, is done digitally shows us that digitalizing technology has such transformation. This situation of Akihiko Kondo also referred to as digital sexuality, forms the research topic of the study. In this article, with digitalizing taking its place in our lives in a big amount, digital sexuality, the causes of effects, its future and its effects on collective life have been approached within the context of digital character-human relations. The case analysis has been done with Akihiko Kondo, who executed a digital marriage, with a qualitative research approach and by the usage of semistructured interview style.

\section{The Development of Artifical Intelligence}

The will of humankind to have the life of his own continue in physical and spiritual safety throughout history has led to many innovations, improvements, and inventions. Since people have a will to shape and change the nature in which they exist. And when they do this change, they invent tools and use them. The aim in this struggle and development process which dates back to more than 4000 years, is the desire to facilitate the life and to travel to the utmost point that science can take and the desire to explore. This motivation, on the other hand, has formed the technical information out of the most meaningful and useful knowledge throughout history. Technical information derives from the Greek word "techne"(tekne) which means skill. The activity to turn the objects in nature into pieces of equipment useful to people is called technical while the knowledge of how to do these pieces of equipment is called technical information (rehberlik.biz.tr, 2012). We can exemplify this type of information resulted from the daily and scientific information being adapted into daily life with the invention of fire, Wheel, printingpress, the telephone. The whole fact made out of all this technical information formation is called technology. According to TDK (Turkish Language Association), technology is handled with two different meanings. First of these; "The applied information which covers the methods of formation of an industry branch, the equipments and tools used, and usage styles of these, technology", while the other meaning is; "the whole information related to the equipment that people invent in order to check and change the material environment of people" take place as its meanings in TDK (TDK, 2019). Technical information; "It is neither a solution to achieve some ideal targets as Spiritualist philosophers put forward or an information type transferred into practice as Positivist philosophers put forward. It is an information variation that individuals use to take control over the world and that can be transformed into technological production" (Engin, 2005).

Technical information is divided into different subtitles in itself. This type of information that also defines the concrete entity field, is examined under three titles which are tool technology, machine technology and automation technology (Yıldırım, 2018). These three titles are under the heel of a timetable that shows the progress of technology in the historical process. The tool technology developed to adapt to nature and to provide the needs in the first age has left its place to machine technology in this process where the control of nature has increased. Manpower that takes an active role in the tool technology has withdrawn itself in this process and with the machines developed it has come to a place where he controls this technology. In the third phase, on the other hand, automation technology has come into prominence. Here, machines have got automatized and they have come to a place where they can do anything through time. Thus, manpower has only a mission to plan, control and check in this phase.

The automation which means that works have been done with machines moving automatically without the human labor in the industry, agriculture, health, technical works in the industry and management but under the man control, is the instrument of the biggest power and control of the developed societies in our era. Here, the important nuance is that science and technic are an inseparable whole. The power-information relation that Michael Foucault (Kılıç, 2014), one of the most influential philosophers of the 21st century, has led its emergence, is eligible to describe this topic. Information that is the most valuable entity throughout history, has made the individual, nation, society, state who owns it powerful and acceptable. Repeatedly, a technology that is also a product of information in our era is keen on to make the community who owns it the power.

The non-stop progress of technical information throughout history owes this situation to the previous knowledge accumulation and experiences of every new invention in a way. This situation called as data in a scientific aspect is a necessary information type to achieve the result based on the previous experiences by reasoning. The chip technology that we have today from the first animal figures that 
mankind drew on the cave walls to this point is essentially a data processing operation (Ergezer et al., 2003).

The point that automation technology has come so far, has been the medium of technology and the changes connected to this. The development of computers, that internet network has covered the whole world, the possibility of an individual to keep in touch not only with the environment of his own but also with the whole world and besides, the fact of digitalizing in every field has made the technology an indivisible part of us. The statement of Steve Jobs, CEO at Applle Computer Inc, that he says as in "A personal computer is a device that supports us as an inseparable part of our intelligence." has shown this situation and the adventure of future. Thus, this adventure has been this fast, dynamic and applicable has been executed due to artificial intelligence.

To develop the artificial intelligence, which is the biggest dream of mankind, and the other machines and devices related to it is a severe investment where it is important and it is a topic of millions of dollars today. The fact that computers that have been the indispensable part of our daily life are able to learn and decide as people do, has enlarged its usage areas. The fact that the problems which are hard to solve by people and cannot be showed with a mathematical formula can be solved by computers with artificial intelligence methods has become a necessity in every area of the automation process. (Çevik \& Dandil, 2012).

Artificial intelligence is also named as artificial neural networks. Because artificial intelligence technology is the study to produce the human brain working method artificially, and have it existed. Man has a neural network processing operation that is able to think, decide, learn, divide, solve and dream. When we look at the technological developments, the inspiration source of all the machines operational are those entities created in nature. And the inspiration source of artificial intelligence technology is the human brain. Artificial intelligence applications have also been known as smart systems. The fundamental feature of smart systems is that they have the feature to produce solutions to the events and problems or to decide in the study phase based on information (Elmas, 2007). The ability to be processed and carried out of these mechanisms have also been possible due to artificial neurel networks (ANN).

It is possible to hear the concept of artificial intelligence more frequently for the last few years. Since it has been the most significant development for the last two or three decades. However, the past of this study dates back to 1308. Catalan poet and theologist Ramon Llull have mentioned a new information variation formed from combinations of concepts in his book named as Generalis Ultima (The Ultimate General Art) (Eco, 2016). Nikola Tesla who introduced the ship that was firstly controlled by radio waves of the world in 1898, called this system "borrowed consciously". In 1924, Leonardo Torres y Quevedo, a Spanish civil engineer, and mathematician introduced a machine that can play chess, a wisdom play. This machine could continue the game without any human interference (Yuste and Palma, 2004). In 1924, "robota" robot word entered into science literatüre by Karel Čapek, the Czech author. In these years, first trials were made for automobiles without drivers. And robots started to take place in science-fiction films. In 1943, on the second hand, the first article was published on artificial neurons. This article in which Warren S. McCulloch ve Walter Pitts told simplified and idealized artificial neurons how these execute rational functions, had been a ground for "neural networks" based on computers (and later on for "deep learning"). At this point, also the term, "imitating the brain" emerged (medium.com). When it came to 1950s, today's groundings of artificial intelligence were fortified by studies, articles and machines made. Here, the most important names are Claude Elwood Shannon who was American mathematician, electrical engineer, and cryptographer and also known as the father of epistemology and Alan Mathison Turing who was English mathematician, computer scientist, cryptographer and also counted as the founder of computer science. Shannon published the first article related to developing a computer program that plays chess. And Turing emerged the criteria about whether machines and computers can have the ability to think with the Turing test he invented. In 1955, John McCarthy (Dartmouth College), Marvin Minsky (Harvard University), Nathaniel Rochester (IBM) and Claude Shannon found out the term artificial intelligence. Finding out artificial intelligence and improving methods gained speed as of these years. In this process, machine learning, artificial neural networks, a program with mutual emotions, smart machines, electronic person, grasping a language, sensational analysis, early alert system, being able to interpret, autonomous car, information navigator, robots and digital assistants came out. Every data discovered here has become both inspiration source for the following one and basis. 
Artificial neural networks that are the combinations of artificial intelligence, emerged due to the result of computer modeling through imitating the working structure of the human brain (Çevik \& Dandil, 2012). This technology that was developed by taking example the human brain in the basic, has offered to learn, to store the data learned, to collect, to classify, to bring into a meaningful whole, and to deduct with these data obtained on a neural network as neurons do in the human brain (Fauset, 1994).

Usage of such features of artificial neural networks to calculate, produce information, to be able to learn and to solve problems have been spreading in many scientific branches and even in many fields today. And it has been continued to be improved for work process optimizations and almost for all production, management processes. The four features of artificial neural networks are being not linear, learning, generalizing, being adaptable, and fault tolerance and these provide the usage of this technology (Ergezer et al.). Artificial neural networks "fulfill such functions as pattern recognition, nonlinear signal processing, association or pattern matching, non-linear system modeling, time series analysis, signal filtering, smart and non-linear control, data compaction" (Çevik\&Dandıl, 2012).

Artificial neural networks which are used in many fields from financial applications to engineering, from industry to medical science in daily life, can do data mining, optic scanning, evaluation, guessing performance with data, face, fingerprint, voice recognition, quality control, evaluation of production results within the framework of safety systems, and forming cartoon character that can exhibit human behaviours, service with digital assistants, analysis of diseases, cell reactions, and mission classifications as treatment (Anderson, 1995).

When we look at this whole improvement of artificial intelligence technology, we can say that both physically and sociologically in human and social life elements and pieces of equipment produced with artificial intelligence can easily be embraced and take its place. With developing technology digitalizing has paved way to changes in the dynamics of an existing culture, identity as it is with everything in societies. Especially, the mobilization of technology has been accelerating this change. Artificial intelligence that accelerates the life cycle with the facilitation it offers, has been changing the shape and structure of norms in which the technology exists. We can witness this technology in every device we have. Telephones are the primary instances for this. Mobile telephones that have more than communication duty, has some features to supply for many works to be done such as connecting to the world with the internet technology, communicating, listening to music, watching film-series, taking photograph or video with a high quality, mounting, forming file, organizing, sending-receiving, sustaining virtual socializing with social platform applications, and repeatedly with applications from health, banking to bureaucratic transactions. Besides all these, one of the most important improvements uploaded to mobile phones is digital assistants. Digital assistants are set upon a system that has artificial intelligence technology, and that can understand the speeches, and solve and respond. Moreover, in 2012, Apple Computer Inc. Introduced Siri digital assistant that it uploaded to mobile phones and it gave place to this assistant in all the following computer, phone, and tablets making Siri a part of iOS operating system. Siri is successful at understanding the words and responding. Nevertheless, comprehending studies of feelings and thoughts have still been carried on. In digital technology, Alexa Speaker of Amazon Echo and Google Home Assistant that are free from telephone or such devices, have been following Siri (Bloomberg, May 2019).

The functions of artificial intelligence technology in our daily lives have spread to a reasonably wide field. An individual who goes to a tendency to talk to machines with digital assistants now assumes that this situation as a part of his life. When we look at from this aspect, the fact that individuals usually get curious about a newly introduced technological production, using it, embracing and accepting are explained as Technology Acceptance Model (TAM) (Davis, 1989). This model at the same time has drawn a map to the users and researcher in the process of explaining the behaviors on using the technology or not and anticipating. (Liao\&Cheung, 2001).

Today, considering the internet and technology fact as achieving pure knowledge and spreading it is against the nature of this huge world now. The artificial intelligence technology, which works like a human brain, and is capable of programming, meets the needs by recognizing them in its own system, has been improving each passing day, and starting to spread into every field. This is one of the most important improvements in the technology world, even the pioneer.

Artificial intelligence also sustains the communication that people need via smart devices besides social media discourses. Hence, digital assistants that are programmed both in phones and specifically 
on a separate device, are one of the most important examples of artificial intelligence development. Humankind has been acting into executing the existence in the digital world along with existing in the real world. This existence has become possible with the existence of technologies developed by artificial intelligence technology. When we look at this situation from the perspective of digital sexuality that forms the study case of the article, being in contact with animation or robot characters composed of artificial intelligence technology, thinking of them as a real person have been leading to digitalizing of cultures as well. In this whole process, we can mention about digital culture, and that an individual exists with a digital identity in the digital world, and that he fulfills the norms of digital culture to sustain his existence.

\section{Existing in The Online Communities: Digital Culture and Digital Identity}

As a result of the digital revolution, the internet has started to take place in every area of life. The internet that digitalizes the individuals, relations and social life because of its own nature, has earned the phenomenon character with the combination of mobile technologies and applications. Here the nuance is seen that digitalizing of all the culture, dynamic, and practices that exist in the real world. With this transformation in which cultural products are transferred into numerical medium, all of the fields of communication have also started to transform (Manovich, 2001). This transformation has been making almost every -one who has the technological possibilities a participant, and finally, the participant culture concept starts to come out in this emerging public space. Henry Jenkins explains this change that social platforms offer as a product of the internet and mobile technology with the concept of "convergence" (Bliben, 2017). Christan Fuchs, on the other hand, defines the participant the concept of participant culture with the fact that audience group, users, consumers, and fans get involved in the production process. (Fuchs, 2014).

Online that is formed on a digital basis, participant culture is essentially a reflection of the digital culture factor. Hence, developing technology has begun to be effective in almost every phase of human behaviors. In the world where they get affected by the rapid development in the communication technologies, now digital systems and their conditions can rule. (Güzel, 2016). We can exemplify this situation with users' profiles, digital identities, images, symbols, spoken language, and new terminologies.

According to Turkish Language Association, culture is "the whole entity of every kind of living style, thought and art in the tradition condition which forms the unity of feeling and thought of a society" (TDK; 2019). And again, for TDK, sociologically it means the whole entity of instruments that are used with each value formed in the cultural, historical and social development process, and used in transferring into the following generations, and that shows the measurement of the sovereignty of people to his natural and social environment. Culture concept is also approached as civilization and modernity. Nonetheless, a culture which is a human production, quid pro quo for the social mobility of people in togetherness with nature and for all the sub-combinations of this mobility. Culture means living, speaking, walking, running, migrating, loving, respecting, thinking, feeling, marrying, having children, producing, consuming, teaching, learning, transferring what is learned, composing individualistic and social rules, applying to rules, collecting, eating, drinking, sleeping, administrating, inventing, exploring, comprehending, giving meaning, believing and even more.

Aristoteles defined culture as the transformation of knowledge into habits. Ernst Cassirer, one of the cultural philosophy philosophers, stated that human is on the focus of culture pointing out the necessity of a functional explanation instead of a substantial explanation which includes varied elements of culture as the philosopher before him (Karslı, 2016).

With the advantage of digitizing, digitalizing that is an important transformation factor of today, has been reflected on every space of life. Adaptation of traditional methods to the developing technology, particularly the birth of informatics and communication technologies, their development and expansion, has been possible with digitalizing. Entering of digitalizing of what is traditional, information, communication technologies, communication through a computer, artificial intelligence, cyber extension, virtual reality, and many more concepts into our lives had led the new media concept (Olcay, 2018) emergence and so as the existence of digital culture. Culture is transferred from person to person, from generation to generation through communication with a mutually transferred method. This symbolic medium has its own coding and encoding styles and its own language on an online basis as well and with this ownership new digital, social and cultural codes are produced (Timisi, 2005). 
With developing technology, the transformation of culture factor has become possible through digital mediums. Virtual mediums that have developed even more with artificial intelligence technology, have started to substitute for one-to-one communication, socializing, existing, entertaining, learning, producing, consuming, loving, speaking and many similar spaces. Naturally, existing norms for actualizing of order and sustainability in real life, have consisted of digital culture as well. According to Manuel Castells who identify technology with society, digital networks have been creating a social morphology of society and it has been changing the cultural processes from the root (Castells, 2016).

Digital culture has been evaluated as a fact that has expanded to different fields, refreshing and changing itself as an answer to what modern capitalist life has contributed to the needs in the middle of the 20th century. (Gere, 2008). Digital culture involves the following fields:

- Computer, mobile phones, digital cameras, modern television and similar technical pieces of equipment that have access to digital culture.

- Cultural factors constituted digitally or in the digital platforms.

- Digitalizing (Digital design of cultural factors, online contents and users play a significant role in the digitalizing process.)

- Accessibility to information. Digital culture has brought up an important and sufficient value for society turn in to an information society through translating different languages with artificial intelligence technology due to the accessibility condition that it has created (Güzel, 2016).

Communication within the scope of digital culture is also called as new media mediated communication. (Binark, 2010). Lévy used "cyberculture" concept (Levy, 2008) in order to explain the culture that changed as a result of surpassing the constraints among human, nature, and technology. The fact that shows that people exist in the real world is called identity. TDK defines the identity as the following: "The whole integrity of signs belong to human as a social entity, conditions that provide one to be a certain person, and all the characteristic features of that person, who a person is." (TDK, 2019) Although the fact that the term, identity, has a very long history, it has just been started to frequently be used and argued as a result of modernity with the 20th century. From this aspect, identity is approached from psychologically and sociologically. "Because human is a social creature before everything, besides the inner dynamics of an organism, social life also have determinant functions in the emergence and shaping of identity." (Aşkın, 2007). These functions contributed to social identity theory. According to social identity theory; it has been acclaimed that identity has an important effect on determining the feelings, thoughts, and behaviors of social groups to which an individual belongs and that social identity changes in accordance with these groups in which an individual is a member. (Tajfel, 1982; Turner, 1978). Identity, in brief, reflects human who is a real creature, in social life and a proof of his existence.

In the informatics age in which we are in, technology has stepped into the cultural transformation process that offers the digital transformation of almost every formation layers and real life. Just like real identities that form culture and have it continued in real life, exist, repeatedly, a digital identity concept that forms and updates this culture exists in digital culture. Social online platforms where interpersonal interaction is intense, have the formation of digital identities been inevitable. In order to be able to exist in these online networks a user account that is, identity is needed. "Social media is thought of as a new place where individuals exhibit self-presentations and identity strategies besides that it plays an active role in producing identity. Social media usage that resolves the constraints of time and place as a result of especially, mobile technology development, has given chance the users the interaction 24/7 both in public and private spaces. Thus, this has covered it with a widespread and popular identity" (Güzel, 2016).

Digital identity is a required system to obtain for almost all applications that exist on the internet and for social platforms such as Facebook, Instagram, Twitter, Reddit. Individual firstly choose a username for himself to be able to exist in a virtual medium and signs up with this username and e-mail in the platform he desires to exist. And he owns an online social digital identity. Here, the anonymous digital identity situation that comes with digitalizing, the lack of privacy, ethics, values, and control mechanisms exist in the real world and the dangers it brings along with themselves is still an area where it has been argued and offered solution suggestions.

One of the most important features of technology is that it is global and making the world global. And digitalizing and online platforms also provide this globalization to be done socially. An individual existing the real world, in essence, is a world citizen with the digital identity he owns. Globalizing has made this required. Inevitably, a global online community has its own rules, norms, network, industry, 
systematic. Anything existing in the real world has been going through a digital transformation process. And naturally, cultural dynamics in real life has also been going through this process. As it is mentioned before, all Dynamics has been digitalized such as speaking, learning, teaching, loving, being loved, proving self, existing, marrying, comprehending, telling. Within this scope, the examples to be given is very large. However, in this article, especially the digital transformation of the marrying process that founds the basis of family structure, has been approached.

An individual's willingness of sharing the feelings with the opposite sex, loving him/her, desiring to be loved, respecting, desiring to be respected, and the need to be happy with all these has been encountered newly and but it is highly possible for this to be popular. An individual with a digital identity starts to have different lifestyle, preferences, and attitudes differentiating from what is in real life. We can give examples to this situation as such: friendship relations communication, the language used, partnership, and marriage preferences. Here one of the most important points to be discussed upon and to be evaluated under a scientific infrastructure is the relationships and marriage dimension.

\section{Digital Sexuality in the Context of Technological Tendencies}

Information society concept has been frequently used in our age. This concept is the basis of rapid changes in information and communication technologies. And it also creates a new structure of society as well. The knowledge that is the most valuable and the most powerful indicator of history, has been strengthened the technological developments and the existence and sovereignty of those societies that own it. With this existence and sovereignty, the structure of society has in fact been changing. Society structure is passing to digital culture process, and thus, some group emerges according to the speed of embracing this culture. "Individuals and societies who accept the change that is the reality of our era, have shown the protection tendency of their habits, on the other hand. Every generation's philosophy, culture, and habits differentiate from each other. Generations are separated from each other with these kinds of characters and scientific studies. With this respect, these generations are classified as "digital inhabitants", "digital immigrants", and "hybrids" within the digital world" (Karabulut, 2015).

Prensky (2001) found out the terms, digital inhabitants and digital immigrants by stating that recently the developments in the technology make differences between the generations. According to him, that network generation who was born into technology and who uses virtual games, and smartphones as if they are familiar with and as if it is a part of themselves are defined as digital inhabitants, on the other hand, those who were born before 1980, met technology later on and strange to digital are defined as digital immigrants. In spite the fact that we do not encounter with it in the literatüre, digital hybrids are defined as such: Those who met technology later on but do not feel stranger to it, and they are ready to use it. And they are described that they are the generation between digital immigrants and digital inhabitants. Hybrids do not find it hard to get used to gain new habits without leaving the old ones. Nevertheless, this is hard to say for digital immigrants. Immigrants are those who resist the change and have difficulty at comprehending it.

Digital culture tendency of digital inhabitants who were born about 15-20 years ago and those of the $80 \mathrm{~s}$ who are digital hybrids are likely to be high. Thus, digital culture is an advantage of technology and informatics age and their tendency to the life shaped in accordance with this culture is also high. That is, these two generations are the ones who have created this lifestyle and have kept it going. For these two cultures, digitalizing is not a strange factor, as McLuhan puts it, it is the extension of humans. When the circumstances are like this, socializing, learning, being active existing, producing, consuming are carried out through these digital canals and platforms. Because these two generations' Technology Acceptance Modelling has developed fast, their lifestyles are parallel to technological developments as well. The simple's example is that we are up against with a generation who cannot go outside without phone, who cannot spend a day without checking on their social media accounts, who do not count the day as lived without posting their daily lives on these social media discourses. Digital platforms that substitute for one-to-one communication and friendship relationships have just been bringing digital and technological tendencies alongside.

Recently, expansion of the usage of online social platforms such as Facebook, Twitter, Instagram, Tumblr, Snapchat has been a remarkable discourse for the relevant technological tendencies. The fact that communication is sustained through these canals hosts fort he partnership and birth of relationships. Now, it should not be odd to mention about those couples who married after conversating on these 
courses. Besides, for a newly met couple to request each other on social media, and to follow each other's daily lives, and making assessments accordingly, or it is a usual situation for an individual's stalking, with our age's jargon, an opposite sex's social media accounts that is, making decision through searching and observing. At this point to which we have come today, finally all relationships have been happening between two alive individuals, however, only the mediums exist as digital canals. Nonetheless, the development of technology has also started to change the dimension and structure.

Today, another relationship dimension intrigued by digital inhabitants and hybrids but newly spoken about and that has not been expanded yet, is the relationship happening between characters who own artificial intelligence technology and real people. And as forming the main topic of the article, this relationship is called as digital sexuality and partnership relationship has brought itself to marriage point.

Before passing to digital sexuality subject; the need for describing the topic of marriage and sexuality that an individual need is required. A marriage that is the initiating point of a life cycle in a family, is one of the most fundamental social systems and institutions that have an important place in the layers of all societies (Demir\&Durmuş, 2015). Özgüven (2009) describes marriage as an institution where two persons from opposite sexes coming together of for such purposes of living together, sharing, and having children. When looked at from this perspective, marriage is that two persons come together officially to found the family structure as the laws find it suitable and that sustain a life together. And sexuality is the situation to provide both biological and spiritual needs of two persons physically. (Gülsün, et al., 2009) defines sexuality as sexual satisfaction and private life that owns social laws that include two persons live in harmony together, value judgments and determined by taboos, and that has biological psychological and social aspects. Sexuality that shapes the life's biologic, psychologic, and sociologic interaction, keeps an important place that creates the life quality to sustain the human life, being one of the building blocks of the family institution and the cause for a child to be born into the world. Under the light of all these explanations, when we look at relationship dimension from the perspective of marriage and sexuality, we can see that a physical, biological, and psychological relationship indispensably two main roles are two alive individuals and two sexes. This situation is also a part of the social culture. Especially marriage owns a very exceptional characteristic and place and it is a cultural factor of which value is huge.

The digital culture that has emerged with the development of technology has started to manipulate the users connecting it to varied technological tendencies. Upon technological tendencies, technology addiction factors (Dinç, 2017) such as online games, internet, social media, online gambling, porn have been gradually showing its effect, and particularly World Health Organization, health authorities, and states have been studying on creating awareness in individuals up against for technology's unavoidable development's negative effects and on developing treatment methods for growing disturbances. Today, one of the most attractive examples of technological tendencies has been lived as digital marriage/sexuality.

Digital sexuality and taking this to the level of marriage stands up as not a frequent one today but its expansion is likely to happen. Digital sexuality and marriage can be described that an individual desire to live all the satisfaction and feelings with the opposite sex, and marriage dimension through devices that owns an artificial intelligence technology and using his sexual tendency and preference in this direction. For the last five years, this topic is approached by two different species from the aspect of sexuality. First one is that individuals choose robots that have human structured skin, face, and body, and that can talk via artificial neural networks, that can understand and move, for their sexual lives. These robots are designed in accordance with the demand of person and they are mostly produced for sexual life to happen. Nevertheless, now the specialists claim that robots could play a role in marriages in the future rather than sexual life. Moreover, Mark Golfeder, Emory University Law Faculty, and again from the same university but in the department of robotics, Joseph Reis have told that if a robot could be accepted as an individual then it would be possible for a wedding to happen (Golfeder\&Razin, 2015). David Levy who is known with his studies on artificial intelligence system, on the other hand, foresaw that in his book named "Love and Sex with Robots" marrying to robots could be done in 2050 (Levy, 2001). Furthermore, "Foundation for Responsible Robotics" based on Holland with the press manifesto called " Sexual Future with Robots" published in 2017, states that in future there could be relationships with robots and that this could affect humankind with an unpredictable level (responsiblerobotics.org, 2017). Specialists who study on robots that are ready to take human's place have intensified their questions on whether a relationship can be set up with a robot, if they could work as sex workers, if 
robots can bring a new social perspective to sex preferences, whether being close to robots leads to isolation, if robots can fulfill therapy, and if they can diminish the rate of sex crimes.

While the situation is as it is, the second type of digital sexuality is the relationship dimension that is lived with a cartoon or anime character. Although the fact that researchers say that this situation has not come to this point yet, it is stated that with the advantage of technology, digital users start to live differently a digital extensively relationship. Digital sexuality is lived upon cartoon, digital characters, when an individual feel love, like for a character that he admires. What differs cartoon characters from robots is that sexual life is not experienced physically. Digital interactions have been gradually substituted for face-to-face connections worldwide. The more such world technology giants as Google, Amazon, Tencent, Apple continue to invest millions to the artificial intelligence system, the more it gets inevitable for humans to start a relationship with smartphones, and all the digital devices as they do with humans. Development of technology is now an inevitable truth. And that this development facilitates every part of life is another reality. However, this development, when this development starts to substitute for human relationships, and when individuals start to show a tendency against their nature, it is a crystal clear truth that is is time to speak, argue, and take measurements regarding the negative effects of technology and what it brings.

This relationship defined as digital sexuality, that has gone to marriage between digital existences and people has recently happened. The marriage of Akihiko Kondo and Hatsune Miku who is the animation character that he admires made a tremendous impact worldwide (japantimes.co.jp, 2018). Despite the fact that he had a chance to marry his own kind or not to marry, the situation of Kondo who married a digital character is described as digisexualism/digital sexualism. Before stepping into this marriage phase that was experienced, recognizing Kondo and Miku would help to understand the main idea of the study.

Akihiko Kondo, aged 36, is a teacher alongside being a principal of a school that educates primary and secondary school children. He admired for Hatsune Miku who owns a fan group particularly in Asia region, and this admiration turned into love as he said. Stating that his relationship tore him apart 10 years ago and relationships between people are exhausting, he wanted to marry Hatsune Miku and with a simple ceremony held in November 2018, he married Hatsune Miku. His family did not attend this wedding since they disagreed. Close friends of Kongo's participated in the ceremony. A marriage made did not gain an official status because it did not respect the law in Japan, however, a document was signed unofficially. In the ceremony, Miku was placed as a stuffed toy in the hand of Kondo, both Miku and Kondo wore rings as a necessity of marriage. The ring was worn by Kondo to Miku, the stuffed toy. The topic whose detailed information that will be given in the research findings is why Kondo preferred such marriage.

Hatsune Miku has been developed by Crypton Future Media Inc.and it is a humanoid character that is vocalized by Vocaloid song synthesizer application (url1). It was designed as a 16 years old girl who is tall, and who has turquoise colored and two-tailed hair. Hatsune Miku, name of the character, means "the first sound of the future" in Japanese. Crypton Media defines Miku as the owner of the way to cyber reputation. The voice of Miku is a product of Vocaloid song synthesis that is a digital voice brought up with signal processing method with being synthesized of more than one person's voices (url2). Miku is a digital singer who has worldwide fans, sings with her own style, dances, perform in a concert (url3), in which thousands of her fans attend with virtual reality and who sings mostly J-Pops and Dance-Pops (url4). Besides, Miku's song has been followed such music platforms as Youtube, Spotify, Deezer, Tuneln with millions of fans of hers.

The marriage and family life of Kondo and Miku's have been going through a hologram structure. Miku is placed in a hologram structure named Gatebox (https://gatebox.ai/home/,2019). Gatebox is a Japanese virtual assistant. The difference of this virtual assistant from such assistants as Siri, Amazon, Alexa is that she is placed in cylinder out of the glass as a hologram of character/assistant. A hologram is a 3D visual processing which is made through a moving method based on laser-lights (Ecevit, 2019). Gatebox services a virtual assistant that makes the requested character reflect with 3D and make it speak with artificial intelligence technology in a cylinder out of glass. And Miku is also placed in Gatebox as a hologram, Kondo, and Miku communicates through this way. Miku, as it happens in every digital assistant, can do daily speeches, say hi, and control the electrical system of the house. Kondo controls the romance of the incident. Except for this, artificial neural networks that Miku owns now is not available to understand feeling and thoughts and mood from the tone. 
This marriage of Kondo and Miku has been evaluated by the experts as an expected possibility to happen but a surprising incident, though. And researchers also state that this incident is a sign of social events that transforms with wider and different technological tendency and technology. Besides, this marriage that Kongo has experienced, could also be a result of running away and recovery resolution from some problems and what he has been through. And this, as it is in every addiction type, shows a resemblance to the situations of people who experiences their escape from such addiction ways as cigarette, alcohol, drugs or social platforms, online games, or gambling (Dinç, 2017). In this type of addiction, the harms that lead to the person himself, to his environment, and to society are clearly seen. However, whether the digital marriage that Kondo experienced is a solution or an escape from the problems is a topic that was being discussed. While the fact that Kondo did not hide from being on the news, it has been told that there have been people who experienced digital marriage but has hidden. What really happens is that it is unusual and a technological sexual tendency is on the case. One's desire to share his feelings with an opposite sex, to love her, to want to be loved, to respect, and to want to be respected, and the need for being happy with all these, has been becoming the gatekeeper of digital marriage topic that has been newly been encountered but possible to expand. This situation, at the same time, due to the fact that it is generally against the nature of human and society, is a subject to be discussed upon.

\section{Methodology}

The reasons for digital sexuality/marriage has been the subject of this article. As we can see in the study, Akihiko Kondo who we can call as a digital hybrid, experienced a marriage with Hatsune Miku, a cartoon character that he admires her lyrics and music. And he based his reasons why this marriage happened onto his mood and experiences of his inner world. The fact that digitalizing has taken place in every part of our lives actively and that we accept this as digital inhabitants and digital hybrids has shown that in the digital culture there can also be different tendencies and preferences. On the other hand, digital marriage is also one of them, and its expansion is the question. Within this scope, there has been executed a semi-structured interview with the qualitative research method with Akihiko Kondo who experienced digital marriage as a method. The interview technique applied in the qualitative research is an effective way for grasping a situation, incident, or person, and truth, for being eligible with defining, and through this setting the content of the study on a scientific ground by analyzing the study case (Yengin, 2017). Besides, semi-structured interviews offer the participant the chance to tell how he perceives and sees the world with his own thoughts (Merriam, 2013).

\section{Data Collecting Method}

In this study, the questions were sent to Akihiko Kondo as written on Facebook with semistructured interview technic, and he was asked to answer the questions. The formation of the interview is originated from the country and language differences. The fact that the general of the interview has no ability to represent and being unable to explain, statistically, the data obtained with semi-structured interview technic that is a qualitative research method, provide the results achieved to a general evaluation through interpreting. Also, the evaluation of the response was approached by a commentative style.

\section{Research Findings}

The questions delivered to Akihiko Kondo and the answers obtained are placed below:

1. How old are you and what is your profession?

I am 35 years old. I'm the principal of a public primary and secondary school.

2. How did you meet Miku?

In 2007, I met her through an internet video site called Nico Nico Douga. As of May 2008, I started to take vocal songs seriously. Her voice and look were very nice. And I started to like her.

3. What kind of character Miku is and what kind of artificial intelligence technology does she have?

Miku is a cartoon animation character and she is also a hologram character special for me because she is in my Gatebox on purpose to talk to her. She is bright and very beautiful. Technically less developed and she needs more updates in the future.

4. What do you think you find in Miku to make yourself feel better? 
I like listening to Hatsune Miku's songs, watching her cute videos and photographs, and following her. This makes me happy. She contributes color to my life.

5. How is your daily communication with Miku?

Miku wakes up in Gatebox in the morning. She says good morning to me. I go to work. When I arrive home, I connect to my phone and Miku enlightens the house. She says farewell to me when I go to work. When I go to sleeping she says good night to me. This how our conversations go.

6. Did you feel lonely before Miku?

I used to believe that I could not find a wife at this young age or getting married. I had a problematic relationship before. I used to feel lonely. But it was all before meeting Hatsune Miku.

7. Why did you prefer marrying a cartoon character instead of a human?

I did not marry a cartoon character but Hatsune Miku. I gave up on falling in love with a normal woman. There is a template where a real man and woman get married, have children and live together as to their happiness. But I don't believe that this kind of template can make everyone happy. I believe that happiness and love are different for every person. In a time where I got involved with online games more, $2 D$ characters got my attention. And again, in this process, I got suspended from my job because of a woman's bullying. I had troubled times. I discovered Hatsune Miku. I could recover with her songs, videos, and photographs, and I got back to my job. Miku is a woman who saved me. After Miku got into my life, my relations with people got better.

9. How is your relationship with technology? Do you see yourself as a technology addict? I do follow technology closely. I can say that I am.

11. Do you think that digital marriage could expand?

Yes, if talking to characters get strengthened this kind of marriage spreads.

12. Answering this question is your preference. Does Miku have an effect on your sexual life? I can say this: I did not see sexual photographs or videos of Hatsune Miku's. Both because of this and in normal I did not have a sexual desire for her, and I do not.

\section{Evaluation of Findings}

In the result of this study made with semi-structured interview technic, we can interpret digital marriage subject as below through sample:

- That Akihiko Kondo met Hatsune Miku happened at the same time when he experienced the bullying of the woman in the workplace and as a result, he got suspended.

- Kondo felt lonely before Miku and isolated himself from people and society.

- He stated that first he got attracted by Miku's voice and then her look.

- The admiration for Hatsune Miku who has a digital voice with Vocaloid voice synthesizer and also is a digital character, that she is at high numbers at music lists, whose concerts are attended by thousands, that her videos are watched by millions of users are remarkable. This situation also shows that digital culture needs to be analyzed from the aspect of consuming.

- That Miku is designed as a 16 years old girl whose body lines are clear, with different hair color and with smooth facial lines is also attractive.

- After the past experiences and unhappinesses of Kondo, his decision-making process that went that far to marry a digital character is also a temper that is needed to be taken care of psychologically.

- Kondo stated that even talking to Miku limitedly make him happy in daily life.

- Kondo defenses that marriage needs to get out of the shape in which two sexes come together and become a family.

- Kondo stated that after Miku, his relations with other people got better and he got back to the job again.

- Although Miku has a general digital assistant features such as saying hi, weather forecast, road status describing, searching on internet, and reading them out loud, making him listen to music, controlling the house items in remote as a Gatebox virtual assistance that is a technological device, can do, Kondo sees her as a life escort and a woman who saved him.

- Giving up on falling in love with a real woman is also a strong excuse for Kondo to marry Miku.

- Kondo stated that he is keen on technology and he achieved to even an upper level that is addiction phase.

- Kondo and Miku have been sharing almost every moment, feeling and thought on social media as written and visually. The interaction of Kondo on Facebook and Twitter posts is very high. And Kondo has a very high follower number. For example, Kondo posted that he planned a vacation with Miku with his followers and took their views. 
- Kondo said that if digital characters' structure is changed that is, their artificial intelligence is developed, digital marriage can also be expanded.

- Kondo responded to the sexual experience question that he was free to answer, saying that he feels no desire for her.

- Although there are some who experienced digital marriage worldwide but hide this from society, that Kondo did not want to hide this kind of situation made a tremendous impact. Also that he is a principal of a school will explicitly get the attention to the topic.

- In his ideas that he gave to the press, Kondo stated that his family and his environment look weird at him. That his family did not attend the wedding ceremony proves this. However, despite all these, Kondo owns this kind of relationship that is completely unusual.

- Repeatedly, according to the news related to the topic, Miku's fans disagreed to this marriage and to the fact that she was possessed. Any explanation has not been made from the company who designed Miku about this relationship.

- The marriage of Kondo and Miku is unofficial. Japanese laws have not made any lawful regulations regarding such a relationship yet. Nonetheless, that Saudi Arabia has given citizenship to robot Sofia that is produced by artificial intelligence technology, is seen enough to defend the idea that digital marriages can be supported lawfully

- According to some views placed on the internet, the marriage of Kondo and Miku is a PR work of the company that is the designer of Miku.

\section{Conclusion}

Digital culture is the inevitable reality of today's world. Thus, technology continues to proceed in every field of our lives and even faster than human. Even such terms as catching up with technology, adapting to it have fallen from favor. Since the explicit feature of technology is that it is fast. However, we are the ones who develop and adapt to it as a culture and even shape our lives accordingly. This situation accepted as a force of today is definitely going to influence the psychology of human and society. As we also have seen in this study, we have started to find it more acceptable that we prefer an isolated life from humans and society and communicating with digital devices or a character, even exceeding the level of technology addiction. First, the causes underlying this escape are needed to be examined. The question " Why humankind escape the society, people, environment, nature briefly life?" is one of the truest questions to be asked. As Richard Sennet puts it in his book called The Fall of Public Man (2013), modern times force people to be an individualistic person by pulling him from the public, making him stranger, and make him private. And to get through this forcing pain easily, it uses the technology as a significant instrument.

Digitalizing technology has been isolating the user from real life by reflecting itself on almost every field of life. And user tries to survive in a virtual, online world. And he sustains his existence in this world with a digital identity. Thus, He makes his communication, contact, shopping, education, entertainment, and many other activities through this canal. With the fact that technology has taken place of mutual communication especially in social relationships, different technological tendencies occur among people.

Technology addiction once was only bounced with watching television and computer screens, now shows itself with such concepts as online games, online gambling, porn, getting anonymous, troll, digital sexuality, marriage and with subproblems. Hence, in 2018, 'Online Game Addiction' that was discussed in the meeting "Effects of Addiction Behaviours to Public Health" to which experts of World Health Organization (WHO) organized under the host of Yeşilay was manifested as 'mental disorder/ behavior disorder' by WHO.

Marrying a digital character that is also the topic of the article, is, in fact, another dimension of marriage. Digital sexuality, the marriage got firstly famous with robots that have a human body and structure and artificial intelligence technology. And this kind of situation is likely to bring a high possibility of many problems on society, family, law, and individual life.

Having a digital relationship emerges as a result of a situation such as loneliness and not being social. Digital relationships that are originated from loneliness, not being able to notice the real life in 
this fast life, fading of approval desires, not being able to stand for another person in the same space, carries a high possibility to take the person further loneliness.

Also, it can be seen in the research findings, that the sample lived a hard relationship before and the bully of the woman in the workplace has taken him away from women. And they took him to a marriage with a digital character. Here the point needs to be indicated is that the sample does not want a woman in his life and that he shows the love that he needs to have for the opposite sex, to a digital character. Besides, for sexual experience, that he does not feel any desire for the digital character and that he does not expect such a thing and he does not need clearly show his attitude against women.

Researchers have not entirely been able to foresee the destiny of digital sexuality, yet. According to experts who claimed ideas regarding the topic, the fact that digital partners take place of a real person is not seen as an easy situation to be expanded. However, the technology that we cannot catch up with its speed, it also speeds up of our lives. When we consider a generation born into the digital that is, digital inhabitants, the need for this situation to be handled consciously. Since, the number of those who have been living such a relationship now, but do not make it heard is very high.

The basic fundamental of marriage is that it is based on a mutual will of the entities. Beyond the lawful criterion, what kind of lawful, psychological, biological, moral and philosophical explanation and force artificial intelligence marriage has, is needed to be approached by specialists of this.

That those sick people who carry such contagious diseases as HIV, AIDS can protect other from themselves by having this kind of relationship and also that he can sustain his biological and social needs stands as another foresight. Additionally, the usage of robots and digital characters is another foresight for these kinds of diseases not to infect and spread.

That the financial and emotional damages of digitalizing that could cause to the family structure should not be seen as "digital, technology, metal device innocence" and protection of family institution, consciousness-raising of parents, children and youth, determining the constraints are another significant perspective.

\section{References}

[1] Anderson, J. A. (1995). An Introduction to Neural Networks, Massachusetts Institute of Technology Press. USA.

[2] Aşkın, M. (2007). Kimlik ve Giydirilmiş Kimlikler. Atatürk Üniversitesi Sosyal Bilimler Enstitüsü Dergisi. Cilt: 10. Sayı: 2. http://e-dergi.atauni.edu.tr/ataunisosbil/article/view/1020000431.

[3] Bilben, O. (2017). Şeffaf Sınırlar: Katılımcı Kültür; Kamusal ve Özel Olanı Yeniden Tanımak. Hacettepe Üniversitesi. https://yenimedya.wordpress.com/2017/01/10/seffaf-sinirlar-katilimcikultur-kamusal-ve-ozel-olani-yeniden-tanimak/.

[4] Binark, M. (2010). Yeni Medya Dolayımlı İletişim Ortamında Olanakların ve OI(a)mayanların Farkında Olmalı. Başkent Üniversitesi İletişim Fakültesi. https://yenimedya.wordpress.com/2010/01/03/yeni-medya-dolayimli-iletisim-ortamindaolanaklarin-ve-olamayanlarin-farkinda-olmali/.

[5] Castells, M. (2016). İletişimin Gücü. İstanbul: İstanbul Bilgi Üniversitesi Publishingları.

[6] Çevik, K. E., Dandil, E. (2012). Yapay Sinir Ağları Için Net Platformunda Görsel Bir Eğitim Yazılımının Geliştirilmesi. Bilişim Teknolojileri Dergisi. Cilt: 5. Sayı: 1. https://dergipark.org.tr/download/article-file/75292.

[7] Davis, F. D. (1989), Perceived usefulness, perceived ease of use, and user acceptance of information technology. MIS Quarterly. 13(3).

[8] Demir, Y. Durmuş, E. (2015). Uzun Evlilikler: Bir Yastıkta Kırk Yıl. Uluslararası Sosyal Araştırmalar Dergisi. Cilt: 8. Sayı: 36.

http://www.sosyalarastirmalar.com/cilt8/sayi36_pdf/5psikoloji_sosyoloji_felsefe/demir_yasin_v d.pdf.

[9] Dinç, M. (2017). Teknoloji Bağımlıı̆ı ve Biz. İstanbul: Yeşilay Publishingları.

[10] Ecevit, N. (2019). Holografi ve Uygulamaları. Gebze Yüksek Teknoloji Enstitüsü. http://maycalistaylari.comu.edu.tr/calistay2009_2/2009-2/2009_2_fizik/2009-

2\%2OFIZIK\%20DANISMAN\%20SUNUMLARI/HolografiVeUygulamalari_Prof_NecatiEcevit.pdf 
[11] Eco, U. (2016). The Ars Magna by Ramon Llull. Institut d'Estudis Catalans. Contributions To Science. https://www.raco.cat/index.php/Contributions/article/download/321162/411647.

[12] Elmas, Ç. (2007). Yapay Zekâ Uygulamaları, Seçkin Publishingevi, Ankara.

[13] Engin, A. O. (2005). Bilginin İnsan Hayatındaki Yeri ve Önemi. Kazım Karabekir Eğitim Fakültesi Dergisi. Sayı:11. https://dergipark.org.tr/download/article-file/31438.

[14] Ergezer, H., Dikmen, M. Özdemir, E. (2003). Yapay Sinir Ağları ve Tanıma Sistemleri. Pivolka Dergisi. Sayı: 6. Başkent Üniversitesi, Bilgisayar Mühendisliği Bölümü. http://www.elyadal.org/pivolka/06/PiVOLKA_06_05.pdf.

[15] Fauset, L. (1994). Fundamentals of Neural Networks. Prentice Hall Inc. USA.

[16] Felsefeye Giriş Notları (2012). http://www.rehberlik.biz.tr/dosyalar/felsefe.ozet.2012.pdf.

[17] Fuchs, C. (2014). Social Media A Critical Introduction. London: Sage.

[18] Gatebox Hakkında. (2019). https://gatebox.ai/home/.

[19] Gere, C. (2008). Digital Culture, Second Edition. London: Reaktion. http://mediaartscultures.eu/jspui/bitstream/10002/597/1/digital-culture.pdf.

[20] Golfeder, M. Razin, Y. (2015). Robotic Marriage and The Law. LSD Journal. https://www.academia.edu/22395135/ROBOTIC_MARRIAGE_AND_THE_LAW.

[21] Gülsün M. Ak, M. Bozkurt, A. (2009). Psikiyatrik Açıdan Evlilik ve Cinsellik. Psikiyatride Güncel Yaklașımlar-Current Approaches in Psychiatry 2009; 1: 68-79. http://dergipark.ulakbim.gov.tr/pskguncel/article/view/5000076433.

[22] Güzel, E. (2016). Dijital Kültür ve Çevrimiçi Sosyal Ağlarda Rekabetin Aktörü: "Dijital Habitus". Gümüşhane Üniversite Iletişim Fakültesi Elektronik Dergisi. Sayı:1. https://dergipark.org.tr/download/article-file/234646.

[23] Hatsune Miku Yine Sahnede. (2019). http://www.roboloko.com/hatsune-miku-yine-sahnede/.

[24] Hatsune Miku-Youtube. (2019). (https://www.youtube.com/watch?v=FoTd918zhZc.

[25] Karabulut, B. (2015). Bilgi Toplumu Çağında Dijital Yerliler, Göçmenler ve Melezler. Pamukkale Üniversitesi Sosyal Bilimler Enstitüsü Dergisi. Sayı 21. https://dergipark.org.tr/download/article-file/411659.

[26] Karslı, Ö. (2016). Ernst Cassirer'de Kültürün Anlamı. Jomelips. Cilt:1. Sayı: 2. Van Yüzüncü Yıl Üniversitesi, Edebiyat Fakültesi, Felsefe Bölümü. https://dergipark.org.tr/download/articlefile/219695.

[27] Kılıç, Muharrem. (2014). Bilgi-İktidar İlişkisi Bağlamında Yasa Düşüncesi: İktidarın Yasal(L)Aşması. İstanbul Üniversitesi Hukuk Fakültesi Mecmuası. S. 1, s. 173-188. https://dergipark.org.tr/download/article-file/97870.

[28] Lévy, P. (2001). Cyberculture. Translated by Robert Bononno. Minneapolis: University of Minnesota Press.

[29] Levy, D. (2008). Love and Sex with Robots. USA: Harper Perennial.

[30] Liao, Z. ve Cheung, M. T. (2001) Internet Based E - Shopping and Consumer Attitudes: An Empirical Study, Information \& Management, 38.

[31] Love in another dimension: Japanese man 'marries' Hatsune Miku hologram. (2018). https://www.japantimes.co.jp/news/2018/11/12/national/japanese-man-marries-virtual-realitysinger-hatsune-miku-hologram/\#. XPKeZ4gzbIV.

[32] Manovich, L. (2001). The Language of New Media, Cambridge: The MIT Press.

[33] Merriam, S.B. (2013). Nitel Araştırma Desen ve Uygulama İçin Bir Rehber, (Çev.Editörü: Selahattin Turan). Ankara: Nobel Publishingları.

[34] Olcay, S. (2018). Sosyalleşmenin Dijitalleşmesi Olarak Sosyal Medya Ve Resimler Arasında Kaybolma Bozukluğu: Photolurking. İstanbul Aydın Üniversitesi Yeni Medya Elektronik Dergisi 2. https://dergipark.org.tr/ejnm/issue/36608/407759.

[35] Our Sexual Future with Robots. A Foundaiton For Responsible Robotics Consultation Report. (2017).https://responsible-robotics-myxf6pn3xr.netdna-ssl.com/wpcontent/uploads/2017/11/FRR-Consultation-Report-Our-Sexual-Future-with-robots-1-1.pdf.

[36] Özgüven, İ. E. (2009). Evililik ve Aile Terapisi (2. Basım). Ankara: PDR Publishingları.

[37] Prensky, M. (2001). Digital Natives, Digital Immigrants. On the Horizon, MCB University Pres. Cilt:9.No:5.https://www.marcprensky.com/writing/Prensky\%20\%20Digital\%20Natives,\%20Digit al\%20lmmigrants\%20-\%20Part1.pdf

[38] Sennett, R. (2013). Kamusal İnsanın Çöküşü. İstanbul: Ayrıntı Publishingları.

[39] Tajfel, H. (1982). "Social psychology of intergroup relations". Annual Revielu of Psychology, 33,1-39. 
[40] Turner, J. ve Brown, R. (1978). "Social status, cognitive alternatives and intergroupre relations." Differentiation betıveen socialgroups: Studies in the social psychology of intergroup relations. (Der.) H. Tajfel.London: Academic Press. 201-300.

[41] Timisi, N. (2005). Sanallığın Gerçekliği: İnternetin Toplum ve Kimlik Alanlarına Girişi. (Derleyenler), Mutlu Binark ve Barış Kılıçbay. İnternet, Toplum, Kültür, İstanbul:

EposPublishingları.

https://www.academia.edu/14723929/\%C4\%BOnternet_Toplum_K\%C3\%BCIt\%C3\%BCr_Derl eme_kitap

[42] Who is Hatsune Miku?. (2019). Crypton Future Media Inc. https://ec.crypton.co.jp/pages/prod/vocaloid/cv01_us.

[43] Vocaolid Virtual Singers. (2019). http://www.vocaloid.com/en/.

[44] Yapay Zekanın Tarihçesi ve Gelişim Süreci. (2019). https://medium.com/t\%C3\%BCrkiye/yapay-zekan\%C4\%B1n-tarih\%C3\%A7esi-vegeli\%C5\%9Fim-s\%C3\%BCreci-cb4c73deb01d.

[45] Yengin, D. (2017). İletişim Çalışmalarında Araştırma Yöntemleri ve Uygulamaları, İstanbul: Der Publishingları.

[46] Yıldırım, Ö. (2018). Felsefeye Giriş Notları. Atatürk Üniversitesi Sosyoloji Bölümü. http://www.felsefe.gen.tr/felsefeye_giris/teknik_bilgi_nedir_ne_demektir.asp.

[47] Yuste, A.P., Palma, M. S. (2004). The First Wireless Remote-Control: The Telekine of Torres Quevedo. Conference on the History of Electronics.

[48] url1, https://ec.crypton.co.jp/pages/prod/vocaloid/cv01_us, 2019.

[49] url2, http://www.vocaloid.com/en/, 2019.

[50] url3, http://www.roboloko.com/hatsune-miku-yine-sahnede/, 2019.

[51] url4, https://www.youtube.com/watch?v=FoTd918zhZc, 2019. 